\title{
A study on the viewpoints of preschool teacher candidates on "Community Service" course
}

Dilek ACER*

\author{
Ayşegül ERGÜL ${ }^{* * *}$
}

\begin{abstract}
This study aims to determine the opinions of preservice trainers studying at preschool education program and to collect their suggestions about "Community Service" course requirement practices. Nineteen third-year pre-service students studying at Ankara University Faculty of Educational Sciences Preschool Education Undergraduate Program participated in the study. The participants have developed projects in groups and carried these out for 8 weeks, 3 hours per week. At the end of the practice, the participants were given a course evaluation form with open-ended questions. The evaluation form consisted of questions about the contributions of the course to the students and the community, problems encountered and support received in addition to student recommendations and comments about the "Community Service" course. Student responses have been summarized and qualitatively analyzed by the descriptive analysis technique. The responses collected have been examined considering the contributions of the course, problems encountered, support received, recommendations and comments.
\end{abstract}

Keywords: Preschool teacher candidate, community, service.

\footnotetext{
* Assist. Prof. Dr., Ankara University, Faculty of Educational Sciences,Ankara,Turkey. E-mail:dilekacer@yahoo.com

${ }^{* *}$ Res. Assist. Dr., Ankara University, Faculty of Educational Sciences, Ankara,Turkey.

E-mail:msen@ankara.edu.tr

*** Res. Assist., Ankara University, Faculty of Educational Sciences, Ankara,Turkey.

E-mail:ayergul@gmail.com
} 


\section{SUMMARY}

Purpose and Significance: This study aims to determine the opinions of pre-service students studying at preschool education program and to collect their suggestions about "Community Service" course requirement practices. As the number of studies on community service is quite low, this research is significant in that it will contribute to the literature about this recently introduced practice that will also build the cooperation between the community and universities.

Methods: The research design of this descriptive study is qualitative. Nineteen third-year pre-service students participated in the study. They were studying at Ankara University Faculty of Educational Sciences Preschool Education Undergraduate Program. After the completion of "Community Service" course students were given an open ended evaluation form during the 2009-2010 academic year spring semester. The data were collected through descriptive analysis of the responses to the evaluation forms. The forms have been read and coded by each researcher separately. For the internal validity of the coding, the forms have been re-coded by different researchers and themes have been formed accordingly. The number of responses per theme has been calculated and some statements have been directly quoted during the interpretation process.

Results: It can be concluded that pre-service students have observed the development of their social awareness, problem solving and organization skills. Furthermore, they have become more experienced in communicating with members of the society from different groups, learnt the value of volunteering for community services, felt self-satisfaction and selfconfidence. They have also gained awareness and experience in the project, teaching practice as well as relations with the non-governmental organizations and institutions.

Discussion and Conclusions: It can be recommended that Community Service experience be shared with the prospective students and the cooperation with the non-governmental organizations be built prior to the practice. In addition, places of easy access to transportation need to be preferred. 


\title{
Okulöncesi Öğretmen Adaylarının "Topluma Hizmet Uygulamaları" Dersi ile Bu Uygulamalara İlişskin Görüşlerinin İncelenmesi
}

\author{
Dilek ACER*
}

\author{
Müge ŞEN**
}

\author{
Ayşegül ERGÜL ${ }^{* * *}$
}

\begin{abstract}
ÖZ. Bu araştırmanın amacı okulöncesi öğretmen adaylarının, “Topluma Hizmet Uygulamaları” dersi kapsamında gerçekleştirdikleri uygulamalar ile bu uygulamalara ilişkin görüş ve önerilerinin belirlenmesidir. Araştırma, Ankara Üniversitesi Eğitim Bilimleri Fakültesi Okulöncesi Öğretmenliği Lisans Programının üçüncü sınıfına devam eden 19 öğrenci ile gerçekleştirilmiştir. Araştırmada yer alan ögrenciler, gruplar halinde ortak projeler geliştirmişlerdir. Geliştirdikleri bu projeleri 8 hafta boyunca, haftada 3 saat uygulamışlardır. Uygulamaların sonunda öğrencilere dersi değerlendirmelerine yönelik açık uçlu soruların yer aldığı bir form uygulanmıştır. Değerlendirme formunda öğrencilerin ders kapsamında gerçekleştirdikleri uygulamaların kendilerine ve topluma olan katkıları, projelerini uygularken karşılaştıkları sorunlar ve kolaylıklar ile "Topluma Hizmet Uygulamaları" dersinin yürütülmesine ilişsin öneri ve eleştirileri sorulmuştur. Öğrencilerin değerlendirme formunda yer alan sorulara vermiş oldukları cevaplar kaydedilmiş ve cevaplarda yer alan ifadeler betimsel analiz tekniği ile özetlenerek yorumlanmışıtır. Formların analizinden elde edilen bulgular ders kapsamında uygulanan projenin aday öğretmenlere ve topluma kazandırdıkları, proje uygulama sürecinde karşılaşılan güçlükler ve kolaylıklar, bu derse ilişkin eleştiri ve öneriler doğrultusunda incelenmiştir. Buna göre; Topluma Hizmet Uygulamaları" dersinin öğretmen adaylarının mesleki gelişimine katkı sağlamakla kalmayıp aynı zamanda özgüven ve iletişim gibi boyutlarda kişisel gelişimlerine de katkı getirdiği belirlenmiştir.
\end{abstract}

Anahtar Sözcükler: Okul öncesi öğretmen adayı, toplum, hizmet.

\footnotetext{
*Yrd. Doç. Dr., Ankara Üniversitesi Eğitim Bilimleri Fakültesi Ankara,Türkiye. E-posta:dilekacer@yahoo.com

** Arş. Gör. Dr., Ankara Üniversitesi Eğitim Bilimleri Fakültesi Ankara,Türkiye.

E-posta:msen@ankara.edu.tr

*** Arş. Gör., Ankara Üniversitesi Eğitim Bilimleri Fakültesi Ankara,Türkiye.

E-posta:ayergul@gmail.com
} 


\section{GíRiş}

Topluma hizmet; geçmişi Aristo ve Platon'un teorilerine dayanan eski bir kavramdır. Bu teorilere göre eğitim, bilgiye dayalı olarak iyi insanlar üretmenin bir aracıdır. Locke, Kant ve Rousseau gibi pek çok düşünür, topluma hizmet ile yurttaşlık bilincini eğitimin hedefleri arasında göstermiş̧lerdir. Dewey ise Demokrasi ve Eğitim adlı kitabında, demokrasi için aktif öğrenmeye dayalı toplum farkındalığını vurgulamıştır (Parker, Myers, Higgins, Oddsson, Price ve Gould, 2009; Niemi, Hepburn ve Chapman, 2000).

Topluma hizmet uygulamaları, demokratik ve insan haklarına dayalı toplum olma yolunda bir yaklaşım olup aynı zamanda demokrasinin, sosyal hukuk devletinin, laikliğin kurumsallaşmasına ve gelişimine; sosyal hizmet uygulama alanıyla hizmet eden bir sorumluluk uğraşı alanıdır. Yaşam kalitesinin yükseltilmesi için geliştirilecek topluma hizmet çalı̧̧maları, sosyal bilimlerin bütün alanlarında üniversite sistemi içinde yetişen tüm bilim ve meslek elemanlarının sorumluluğudur (Şeker, 2009).

Topluma hizmet uygulamaları üniversite eğitimiyle bütünleşmeye oldukça açık bir alandır (Parker ve diğ., 2009). Eğitim kurumlarındaki topluma hizmet uygulamaları, son y1llarda ülkemizde olduğu kadar diğer ülkelerde de gittikçe artan bir öneme sahip olmaya başlamıştır. Yapılan pek çok araştırma, topluma hizmet uygulamalarının; öğrencilerin özgüvenini artırdığını, liderlik becerilerini geliştirdiğini, toplumla bütünleşmelerini ve mesleklerinde daha başarılı olmalarını sağladığını göstermektedir. Ayrıca, bu yöntemle yetişen öğrencilerin sorumluluk duygusu ve önderlik özelliklerinin geleneksel eğitimle yetişenlerden daha yüksek olduğu saptanmıştır. (Bender ve Jordaan, 2007; Schmidt, Magzoub, Feletti, Nooman ve Vluggen, 2000). Öğretmen yetiştiren eğitim fakültelerinde önemi kavranan ve öğretmenlik mesleğine katkısı bilinen topluma hizmet uygulamalarının; öğretmen adaylarının ve öğretmenlerin ülke sorunlarına eğilmeleri ve bu sorunların çözümüne ilişkin çabalarında yaşamsal öneme sahip olduğu söylenebilir (Şeker, 2009).

Topluma Hizmet Uygulamaları, aynı adı taşıyan bir ders kapsamında öğrencilerin mesleki beceriler ile yurttaş olma bilincini kazanmalarını sağlayan, aynı zamanda toplumun ihtiyaçlarının karşılandığı uygulamaları ifade eder. Bu süreçte öğrenci derslerde öğrendiği teorik bilgiyi uygulamaya dönüştürme firsatına da sahip olabilir. Aynı zamanda öğrenci aktif öğrenen konumundadır. Kişi, aile ve toplumla nasıl ilişki kurulacağını, toplum sorunlarına nasıl tanı koyacaklarını, buna karş1 nasıl bir eylem başlatacaklarını ve kişileri bu yönde nasıl harekete geçireceklerini öğrenirler. Toplum içinde yaşayarak ve çalışarak yaşamı ve kültürü daha iyi kavrayarak, alçak gönüllülük gibi bazı etik değerler geliştirirler (Parker ve ark., 2009; 
Fritz, 2002; Rashotte, 2002; Schmidt, Magzoub, Feletti, Nooman ve Vluggen, 2000). Topluma hizmet, bir eğitim kurumu tarafından planlanmasına rağmen o kurumdaki eğitim programı ile bağlantısı olmayan topluma dönük gönüllü çalışmaları içerir (Niemi ve diğ., 2000). Adından da anlaşılacağ1 üzere topluma hizmet uygulaması gücünü toplumdan alan ve topluma dayalı bir süreci içermelidir. Topluma dayalı eğitimin başarılı olması için;

- Açıkça tanımlanmış amaçları olmalıdır.

- İyi planlanmış olmalıdır.

- Tüm bölümlerin ve öğretim elemanlarının katılımıyla yürütülmelidir.

- Edilgen değil problem çözmeye dayalı etkin öğrenim yöntemleri kullanılmalidir.

- Toplum katılımı sağlanmalıdır (Aytekin, 2002).

Bunlara ek olarak topluma hizmet uygulamalarının kabul edilebilirliği ve başarısı demokrasi kültürünün olanaklarıyla ilişkilidir. Toplumsal gelişmenin unsurlarından olan eğitimin sosyal adalet ilkeleri içinde kalarak, ülkemizi hep bağımsız kılacak, hep kalkındıracak, hep ileriye götürecek amaçlar doğrultusunda algılanacak ve yapılacak planlamalar çerçevesinde, öğrenci yeteneklerini geliştirerek yönlendirecek, sosyal yurttaş olarak onların kişiliklerini zenginleştirecek çok yönlü bir paradigma eğitim modelimizde yer almalıdır (Şeker, 2009).

Sosyal bilincin gelişmesini sağlayan topluma hizmet uygulamalarının başarılı olması için eğitim kurumları ile toplumdaki diğer kurum ve kuruluşların koordineli çalışmaları gerekmektedir. Burada eğitim kurumlarından kastedilen özellikle öğretmen yetiştiren üniversitelerin ilgili fakülteleridir. Öğretmenlik bilgisi; disiplin, meslek ve uygulama bütünlüğünden dolayı diğer sosyal bilim dallarından görece daha karmaşı, değişik ve gelişen bir yapıya sahiptir. Öğretmenlerin topluma hizmet bilgisini nasıl kullanmaları gerektiği günümüzde tartışması süren konulardan biridir. Öğretmenlik mesleğinin geleceği için daha rasyonel, etkili ve verimli sonuçlar doğuracak topluma hizmet uygulamalarını içselleştirmesi gelişim için gerekli görülmektedir. (Herzberg, 1994; Şeker, 2009).

Öğretmen yetiştiren eğitim fakülteleri, araştırma ve öğretim işlevlerini yerine getirmelerine ek olarak, yakın çevrelerinden başlayarak ülke geneline ve insanlığa hizmet sunması beklenen kurumlardır. Eğitim fakülteleri toplumsal yaşamın zenginleşmesine önemli katkılarda bulunabilirler. Ülkemizde öğretmen yetiştiren fakültelerin çokluğu ve çeşitliliği, topluma hizmet uygulamalarının yaygınlaştııılması ve etkili bir şekilde gerçekleştirilmesi için büyük bir potansiyeldir. Söz konusu öğretmen yetiştirme programı, öğretmen adaylarının birlikte çalışacakları veya hizmet verecekleri hedef gruplarını belirlemelidir. Hedef gruplar okulöncesi, 
ilköğretim ve orta öğretim öğrencileri, gençler, engelliler, yetişkinler, yaşlılar, yabancılar, ev hanımları, sokak çocukları vb olabilir (Anonim, 2009; Coşkun, 2009).

Türkiye'de üniversiteler bağlamında henüz çok yeni olan topluma hizmet uygulamaları, başta Amerika Birleşik Devletleri olmak üzere pek çok ülkede uygulanmaktadır (McLellan ve Youniss, 2003). Avustralya'da bulunan Queensland Teknoloji Üniversitesi'nde lisans öğrencileri ile yapılan bir topluma hizmet uygulaması sonrasında öğrencilerin yansitıcı günlükler aracılığ 1 ile süreci değerlendirmeleri istenmiştir. Öğrencilerin üçte ikisi gelecek yaşantılarında da gönüllü çalışmalarda yer almak istediklerini ifade etmişlerdir (Parker ve diğ., 2009). Bir başka çalışmada üniversite öğrencileri, sosyoloji dersi kapsamında 4 hafta boyunca haftada en az 3 saat hastaneler ve yetişkin bakım merkezleri gibi kurumlarda 2-3 kişilik gruplar halinde gönüllü olarak çalışmışlardır. Öğrenciler çalışma sonunda hem kişisel hem de akademik anlamda tatmin edici bir deneyim yaşadıklarını ve bu sürecin sadece dersten başarılı bir not almanın verdiği hazdan çok daha fazlasını ifade ettiğini belirtmişlerdir (Rashotte, 2002). Lise öğrencileri ile yapılan bir topluma hizmet uygulamasında, öğrenciler böyle bir çalışmanın içinde yer alma nedenlerini; başkalarına yardım etmek, kişisel tatmin ve toplum üyesi olma bilincini geliştirmek şeklinde sıralamışlardır (Astin ve Sax, 1998).

Ülkemizde geçmişi henüz çok yeni olan topluma hizmet uygulamalarına yönelik yapılan araştırmalar (Çetin ve Sönmez, 2009; Haktanır, Akgün, Duman ve Karaman, 2010; Dinçer, Ergül, Şen ve Çabuk, 2011) bulunmaktadır. Yapılan araştırmaların sayısının az oluşu dikkate alındığında; bu çalışmanın, toplum ile üniversitelerin buluşmasını sağlayacak olan topluma hizmet uygulamalarına önemli katkılar sağlayacağı düşünülmektedir.

\section{Araştırmanın Amacı}

Okulöncesi öğretmen adaylarının, "Topluma Hizmet Uygulamaları" dersi kapsamında gerçekleştirdikleri uygulamalar ile bu uygulamalara ilişkin görüş ve önerilerinin belirlenmesidir. Böylelikle eğitim fakültelerinde "Topluma Hizmet Uygulamaları" dersinin kapsam ve içeriğinin geliştirilmesine yönelik çıkarımlara ulaşılması da amaçlanmıştır.

\section{YÖNTEM}

Çalışma betimsel bir durum saptaması niteliğinde olup, nitel araştırma teknikleri temel alınarak desenlenmiştir. Nitel araştırma teknikleri, ölçümden daha çok açıklamayı olanaklı kılacak olay ve olguların içinde gerçekleştiği durumu dikkate almayı önemsemektedir (Yıldırım ve Şimşek, 2006). 
Okulöncesi öğretmen adaylarının "Topluma Hizmet Uygulamaları" dersinde kazanmış oldukları bilgi ve beceriler ile derse ilişkin beklenti ve önerilerinin belirlenmeye çalışıldığı bu araştırmada nitel araştırma tekniklerinden betimsel analiz kullanılmıştır. Betimsel analiz, bir metni anlamada ve yorumlamada, öznel etkenlerden kurtulmayı sağlayarak, metnin görünen ve ilk bakışta algılanan içeriği yerine, gizil, üstü örtülü içeriğini ortaya çıkarmayı sağlamaktadır (Bilgin, 2006).

\section{Katılımcilar}

“Topluma Hizmet Uygulamaları” dersinin, Lisans Programı’nın üçüncü yılında yer alması nedeniyle araştırmaya, 2009-2010 eğitim öğretim yılında Ankara Üniversitesi Eğitim Bilimleri Fakültesi Okulöncesi Öğretmenliği lisans programı üçüncü sınıfta okuyan 19 aday öğretmen katılmıştır. Topluma Hizmet Uygulamaları dersi; Eğitim Fakültelerine gönderilen yönerge doğrultusunda dersin yürütüldüğü anabilim dallarındaki öğretim üyelerinin her birinin adına açılmaktadır. Okulöncesi Eğitimi Anabilim Dalı'nda üç öğretim üyesinin bulunması ve bu dersi toplam 59 öğrencinin alması nedeniyle her bir öğretim üyesine yaklaşık 20 öğrenci düşmektedir. $\mathrm{Bu}$ nedenle araştırmada 19 aday öğretmen yer almıştır. Araştırma grubunda yer alan katılımcılar gönüllülük esasına dayalı olarak araştırmada yer almışlardır.

\section{Süreç}

14 hafta süren "Topluma Hizmet Uygulamaları" dersinin ilk haftasında sorumlu öğretim elemanları tarafından dersin amacı ve kapsamına ilişkin açıklamalar yapılmış ve Ankara Üniversitesi'nin "Topluma Hizmet Uygulamaları" dersine yönelik yaklaşımı öğrencilerle paylaşılmıştır. Ankara Üniversitesi Eğitim Bilimleri Fakültesi'nde ilk kez 2008-2009 EğitimÖğretim Yılı'nda uygulanmaya başlayan "Topluma Hizmet Uygulamaları" dersi öğretmen adaylarının yaşadıkları toplumda olumlu ve kalıcı izler bırakan dönüşümler yaratmalarını, aynı zamanda öğrencilerin toplumsal duyarlılıklarının artmasını hedeflemektedir (Anonim, 2009).

İkinci hafta öğrencilerden toplumda hizmete gereksinim duyabilecek kimlerin olabileceği konusunda araştırma yaparak gelmeleri istenmiş ve bu kişilere ne tür bir katkıda bulunabilecekleri konusunda tartışmalar yapılmıştır. Üçüncü hafta öğrenciler gruplara ayrılarak Ankara ilinde bulunan sivil toplum örgütlerini araştırıp, bunlar hakkında tanıtıcı, kısa sunumlar yapmışlardır. Dördüncü haftadan itibaren artık şekillenmeye başlayan topluma hizmet projeleri hakkında iki hafta boyunca beyin firtınası tekniği ile karşılıklı olarak düşünceler olgunlaştırılıp proje içerikleri 
oluşturulmuştur. "Topluma Hizmet Uygulamaları" dersi kapsamında öğrenciler toplam 6 grup olarak proje geliştirmişler ve bu projeleri 8 hafta boyunca uygulamışlardır. Oluşturulan projelere ilişkin bilgiler aşağıda yer almaktadir.

Projenin Adl: Neşeli Günler

Amacl: Alt sosyo-ekonomik düzeydeki okulöncesi dönem çocuklarının eğitimlerine destek olmak.

Gerçekleştirildiği Yer: Türkiye Eğitim Gönüllüleri Vakfı Ankara Semahat Dr. Nusret Arsel Eğitim Park1

Neler Yapıldı?: 15-20 çocuktan oluşan 3 ayrı anasınıfı grubuyla sanat, müzik, oyun, fen, matematik ve dil etkinlikleri gerçekleştirildi.

Projenin Adl: Hadi Beni Güldür Biraz

Amacı: Çocukların hastane ortamında eğitimlerine destek vermek ve eğlenmelerini sağlamak.

Gerçekleştirildiği Yer: Ankara Üniversitesi Çocuk Sağlığı Hastalıkları Hastanesi

Neler Yapıldı?: Hastanede yatmakta olan 2-15 yaş arası çocuklarla oyuncak tasarımı, öykü okuma, kukla gösterisi, gölge oyunu, müzikli oyunlar ve çeşitli boyama etkinlikleri yapıldı.

Projenin Adt: Gelecek Ellerimde

Amacı: Sokakta çalışan ve yaşayan çocukların eğitimlerine destek vermek Gerçekleştirildiği Yer: Güven, Eğitim ve Sağlık Vakfı

Neler Yapıldı?: Vakıf merkezine gelen çocuklarla okul derslerine yardımcı çalışmalar ve çeşitli el işi etkinlikleri yapıldı.

Projenin Adl: Anadolu Çağdaş Eğitim Vakfı Cumhuriyet Halk Eğitim Evi Amacı: Cumhuriyet Halk Eğitim Evi'nde anneleri kursa gelen 4-6 yaş grubu çocukların planlı etkinliklerle gelişim alanlarının desteklenmesi.

Gerçekleştirildiği Yer: ANAÇEV Cumhuriyet Halk Eğitim Evi bünyesindeki Okul Öncesi Eğitim Sınıfi

Neler Yapıldı?: Origami tekniği ve artık materyaller ile kukla yapımı, kitap okuma, hareketli oyunlar, parmak boyası ile resim yapma, tekerleme ve şark1 öğretimi, çeşitli malzemelerden resim çerçevesi, mobil ve marakas gibi ürünlerin yapımı gerçekleştirilmiştir.

Projenin Adl: Homofobi ve Transfobiye Son!

Amacı: Ankara Üniversitesi Cebeci Yerleşkesi'nde yer alan fakültelerde öğrenim gören öğrencilerin ve diğer bireylerin homofobi ve transfobi hakkında bilgi sahibi olmalarını ve farkındalık kazanmalarını sağlamak.

Gerçekleştirildiği Yer: Ankara Üniversitesi Cebeci Yerleşkesi 
Neler Yapıldı?: Konuyla ilgili broşür hazırlama ve dağıtımı, Kaos GL Derneği üyeleri ile söyleşi düzenlenmesi, Eğitim Bilimleri Fakültesi kantininde konuyla ilgili yayınların bir stant açılarak paylaşımı, konuyla ilgili film gösterimi, açık pano asılarak görüşlerin toplanması, Eğitim Bilimleri Fakültesi kantin bahçesinde dilek ağacının hazırlanması çalışmaları yapılmıştır.

Projenin Adl: Aslında Her Şey Ben Düşlediğim İçin Var!

Amacı: Okulöncesi eğitim kurumuna devam etmeyen 3-6 yaş çocukları ile ilköğretim okuluna devam eden gecekondu bölgelerindeki 7-12 yaş aras1 çocukları düşünmeye yönelterek yaratıcılıklarını güçlendirmek ve kendilerini farklı şekillerde (drama, resim, müzik) ifade etme becerilerini desteklemek.

Gerçekleştirildiği Yer: Ankara Üniversitesi Eğitim Bilimleri Fakültesi Drama ve Resim derslikleri ile fakülte bahçesi.

Neler Yapıldı?: Mamak bölgesinde yaşayan ve hedef kitleyi oluşturan çocuklar ile ailelerine ulaşılarak çalışma konusunda bilgilendirme çalışmaları, çocukların evlerinden alınıp fakülteye getirilerek planlanan etkinliklerin (boyama, artık materyalden ürün yapımı, drama ve müzik) uygulanması ve oyuncak müzesi ziyareti gerçekleştirilmiştir.

\section{Verilerin Toplanması}

Araştırmada yer alan öğretmen adaylarına "Topluma Hizmet Uygulamaları" dersi tamamlandıktan sonra dersi değerlendirmeye yönelik açık uçlu sorulardan oluşan bir anket uygulanmıştır. Böylelikle zengin ve yeterli bilgi toplanması hedeflenmiştir (Büyüköztürk, Kılıç Çakmak, Akgün, Karadeniz ve Demirel, 2009). İç geçerliği sağlamak için anket üç alan uzmanının görüşüne sunulmuştur. Uzmanların önerileri doğrultusunda ankete son şekli verilmiştir. Anket araştırma amacı ile kullanılmadan önce bir öğretmen adayı ile pilot uygulama yapılmış ve soruların açık ve anlaşılır olduğu saptanmıştır. Aday öğretmenlere sorulan sorular aşağıda yer almaktadır:

1. Bu ders kapsamında uyguladığınız projenin size kazandırdıkları nelerdir?

2. Bu ders kapsamında uyguladığınız projenin topluma kazandırdıkları nelerdir?

3. Projeyi uygularken karşılaştı̆̆ınız güçlükler nelerdi?

4. Projeyi uygularken yaşadığınız kolaylıklar nelerdi?

5. "Topluma Hizmet Uygulamaları" dersine ilişkin eleştirileriniz nelerdir?

6. "Topluma Hizmet Uygulamaları" dersine ilişkin önerileriniz nelerdir? 
Anket araştırmacılar tarafindan aday öğretmenlere toplu bir biçimde uygulanmış ve anket formunda yer alan açık uçlu soruları yanıtlamaları için 30 dakika süre verilmiştir. Araştırmayı yürüten, aynı zamanda öğretmen yetiştiren Eğitim Fakültesinin Lisans programında görev yapan öğretim elemanlarının iş yükünün (lisans derslerinin takibi, öğrencilerin uygulama okullarında izlenmesi vb. ) fazla oluşu ve yeterli zamanın bulunamamış olmasından kaynaklı olarak bu araştırmada görüşme tekniği yerine anket uygulanmıştır.

\section{Verilerin Analizi}

Veriler, anket formuna kaydedilen aday öğretmenlerin cevaplarında yer alan ifadelerden elde edilmiştir. Verilerin çözümlenmesinde betimsel analiz tekniği kullanılmıştır. Betimsel analizin amacı, ham verilerin okuyucunun anlayabileceği ve isterlerse kullanabileceği bir hale getirilmesidir. Bunun için veriler araştırma sorularının ortaya koyduğu temalara göre oluşturulur ve formda yer alan sorular dikkate alınarak sunulur (Yıldırım ve Şimşek, 2006).

Sorulara verilen yanıtlar betimsel analiz tekniği ile özetlenmiş ve yorumlanmıştır. Betimsel analizin ilk aşaması olan "çerçeve oluşturma" kapsamında proje sürecinde kazanılan kişisel ve toplumsal yarar, proje uygulamada yaşanan zorluklar ve kolayliklar, derse ilişkin öneriler başlıklı temalar oluşturulmuştur. "Tematik çerçeveye göre verilerin işlenmesi" olan ikinci aşamada değerlendirme formları araştırmacılar tarafından ayrı ayrı okunmuştur. Ardından araştırmacılar kodlamaya ilişkin iç tutarlılığ 1 sağlamak için değerlendirme formlarını birlikte tekrar incelemişlerdir. Veriler, temalar doğrultusunda anlamlı ve mantıklı biçimde bir araya getirilmiş ve kodlanmış ve fikir birliği ile kategoriler oluşturulmuştur. Kategorileri oluşturmada "proje sürecinde kazanılan kişisel yarar" temasında yer alan "duygusal (manevi) doyum" kategorisine ilişkin aşağıdaki alıntılarda altı çizilerek belirtilen kodlar temel alınmıştır:

"Proje ile her şeyin ders olmadı̆̆ını fark ettim. Çünkü benim için önemli olan dersten gelecek puan değil o çocuklarla birlikte vakit geçirmekti." Z.U.

“...yeni çevreler edinmek, bir şeyleri yapmak için kendi çabamızı sarf etmek ve bunu yaptı̆̆ımızda yaşanan o başarı duygusunu tatmak çekilen tüm yorgunluğa ve emeğe değer." G.E.

Kategoriler oluşturulurken betimsel analizin üçüncü aşaması olan "bulguların tanımlanması" aşamasında verilerin anlaşılırlığını güçlendirmek amacıyla kullanılacak doğrudan alıntılar da belirlenmiştir. Üçüncü aşamada 
kategorileri olușturan alıntılardan örnekler verilmiș ve kategorilere ilişkin frekans dağılımları belirtilmiştir. Betimsel analizin dördüncü ve son aşaması olan "bulguların yorumlanması" kapsamında bulgular açıklanmış ve tartışılmıştır (Yıldırım ve Şimşek, 2006).

\section{BULGULAR}

$\mathrm{Bu}$ bölümde değerlendirme formunda yer alan sorulara aday öğretmenlerin vermiş olduğu yanıtlardan elde edilen bulgular yer almaktadır. Değerlendirme formu, aday öğretmenlerin yanıtlarını yazmalarının istendiği açık uçlu sorulardan oluştuğundan, her soruya ilişkin verilen yanttlar katılımcı sayısı ile tam olarak uyuşmayabilir. Aday öğretmenlerin farklı projeler yürütmesi nedeniyle sorulara verilen yanttlar projenin topluma kazandırdıkları, uygulanmasında karşılaşılan güçlükler ve uygulamada karşılaşılan kolaylıklar açısından da farklılaşmaktadır.

\section{Projenin Aday Öğretmenlere Kazandırdıklarına İlişskin Bulgular}

Aday öğretmenlerin çoğunluğu $(\mathrm{n}=11)$, gerçekleştirdikleri projelerin topluma karşı sorumluluklarının farkına varmalarını sağladığını belirtmişlerdir. Buna ilişkin ifadelerden bazıları şöyledir:

“ ... uyguladı̆̆ımız proje, toplumsal duyarlılı̆̆ımın artmasını ve içinde yaşadığım toplumun sorunlarının çözülmesinde somut ve olumlu izler bırakmamı sağladı” G.K.

“ Bir öğretmen adayı olarak toplumun çeşitli özelliklerini tanırsam ileride hizmet vereceğim kurumda toplumsal özelliklerin neden olduğu sorunları daha kolay çözebileceğimi fark ettim... Topluma hizmet uygulamaları kapsamında yaptığım uygulama duyarlılık, farkındalık, işbirliği, dayanışma, iletişim kurma, toplumsal sorumluluk bilinci gibi çeşitli becerilerin gelişmesine katkı sağladı” S.G.

"Bütün bu yaşananlar bana artık büyüdügümü ve çeşitli sorumluluklarım olduğunu, en önemlisi ise artık öğrencilikten çıkmaya başladı̆̆ımı yani artık bir sorun olduğunda görüşecek velim olmadı̆̆ını, aksine ilgilenmekle yükümlü olduğum öğrencilerin velileri olduğunu anladım” Y.A.

Projelerin aday öğretmenlere kişisel olarak kazandırdıkları arasında yer alan bir diğer kategori ise "Gönüllülüğün topluma hizmette esas oluşunu kavrama" olarak belirlenmiştir. 8 aday öğretmen bu kategoriye hizmet eden yanıtlar vermişlerdir. Bu yanıtlar;

"Bu proje gönüllülük esaslı bir proje. İsteyerek, severek yapllmadiğ sürece stajdan farki olmaz kişi için. Fakat dersin kapsaminda olan yerlerde vicdanin devreye girmemesi imkansiz" S.G. 
"Uyguladı̆̆ımı bu proje bana gönüllülü̈̆̈̈n esas olduğunu anlamamı sağladı. Bu projeyi ders olarak değil de gönüllü bir eğitimci olarak yapmaya başladığım an dersle alakalı tüm yükler üzerimden kalktı" M.K.

“...En önemlisi ders olarak başlayan ve daha sonra gerçekten gönüllü olarak yaptığım bu proje bana toplumun sorunlarının farkinda olmamın yetmeyeceğini, onları değiştirmek için aslında elimde birçok firsat olduğunu gösterdi" C.K.

"Gönüllülüğün topluma hizmette esas oluşunu kavrama" kazanımına paralel olarak, "Duygusal (manevi) doyum" kategorisi de aday öğretmenlerin $(\mathrm{n}=2)$ belirttiği bir diğer noktadır:

"Proje ile her şeyin ders olmadı̆̆ın fark ettim. Çünkü benim için önemli olan dersten gelecek puan değil o çocuklarla birlikte vakit geçirmekti." Z.U.

"...yeni çevreler edinmek, bir şeyleri yapmak için kendi çabamızı sarf etmek ve bunu yaptığımızda yaşanan o başarı duygusunu tatmak çekilen tüm yorgunluğa ve emeğe değer." G.E.

Öğretmen adayları $(n=3)$ ders kapsamında bulunulan girişimler ve yapılan uygulamalar sürecinde "Özgüven kazanma/artışı" kategorisine vurgu yapmışlardır. Bu kategoriye ilişkin en çarpıcı örnek aşağıda verilmiştir:

"Topluma Hizmet Uygulamalart" dersi bana kendi başıma bir amaca yönelik, faydalı bir şeyler yapabilme duygusunu tattırdı. Kendime olan özgüvenim arttı." K.E.

"Organizasyon becerisi kazanma" kategorisini vurgulayan dört öğrencinin yanıtlarından biri ise şöyledir:

“...tamamen özgür olduğumuz projede çocukları bulmak, gibi görevlerin hepsini biz organize ettik. Yeri geldi yaptı̆̆ımız yanlıs teknikler yüzünden aileye açılamalar yapma zorunluluklarımız oldu" Y.A.

Aday öğretmenler tarafından kazanım olarak değerlendirilen bir diğer kategori ise "Ailelerle iletişim kurmak ve güvenlerini sağlamak" olarak belirlenmiştir. Bu kategoriye ilişkin altı aday öğretmen görüş bildirmiştir. $\mathrm{Bu}$ görüşlerden bazıları şöyledir:

"Farklı kişilerle tanışmak ve iletişim kurmak konusunda beni geliştirdi" Z. U.

"Uygulamalar sayesinde çocuklarla ve aileleriyle (özellikle anneleriyle) olan iletişimim gelişsti" S.G.

Diğer yandan beş aday öğretmen de "Problem çözme" kategorisi doğrultusunda kazanım elde ettiklerini şu yanıtlarla bildirmişlerdir: 
"Uygulama sürecinde yaşanılan zorlukların neler olduğunu görerek bununla ilgili çözümler geliş̧tirmeyi öğrendim” D.G.

"Bundan sonraki yaşantımda bir şeylerden şikâyet etmek yerine düzelmesi için ben de neler yapabilirim diye düşüneceğimden eminim" C.K.

“...ve projenin bana diğer bir katklsı da tüm olumsuzlukların olumlu bir şeye dönüssebileceğini görmem oldu” M.K.

Aday öğretmenlerin bir kısmı, yürüttükleri proje çalışmasının kendilerine proje konusu hakkında bilgi ve farkındalık kazandırdığını ifade etmişlerdir $(\mathrm{n}=8)$. Bu ifadelerden bazıları şöyledir:

"“'Homofobi ve Transfobi'ye Son!" projesiyle birlikte eşcinsel, transseksüel ve biseksüel sorunları hakkında derin bir farkındalığım oluştuğuna inaniyorum... Proje sayesinde, Ankara Üniversitesi homofobi karşıtı öğrencilerin oluşturduğu, Eğitimde Cinsel Ayrımcllı̆ga Hayır Komisyonu toplantılarında yer almam ve bu sayede diğer etkinliklerden ve sorunlardan haberdar olmam; Türkiye Geneli Homofobi Karşıtı Öğrenci Buluşmasinda, okulöncesinde cinsellik hakkında bilgi verilen sunumda yer almam benim için diğer önemli katkllardandi" E.Ö.

“... sosyo-ekonomik düzeyleri düşük ailelerin olduğu sokaklarda çocuk ararken iyi ve nitelikli anlamda eğitime muhtaç olan ne kadar çok bireyin ve çocuğun olduğunun farkina vardim. ... Tüm bu ögrendiklerim ve farkina vardıklarım ile toplum bilincim arttı. Bundan sonra topluma daha faydall olmaya, mezun olduğumda öğretmenlik yapacă̆ım yörelerdeki bu tip eğitime muhtaç yetişkinlere ve çocuklara faydalı olabilmek için farklı etkinlikler düzenlemeye karar verdim" S.Ü.

Aday öğretmenlerden bazıları ise $(n=7)$ "Öğretmenlik deneyimi edinme" kategorisine vurgu yapan yanıtlar vermişlerdir.

"Bu proje sayesinde belki de yaptığım ya da yapacă̆ım hiçbir stajda elde edemeyeceğim ögretmenlik deneyimi elde ettiğime inaniyorum" Y.A.

"Teorik olarak ögrrendiğim bilgilerimi uygulama şansını elde ettim" D.G.

"Gittiğimiz yer sosyo-ekonomik düzeyi düşük bir yerdeydi. Gerçekten de çocukların nerdeyse tüm gelişim alanlarında geri olduklarını gördük. Bu da bize ilerde bu tip yerlerde görev alırsak nasıl davranmamız gerektiği ile ilgili ciddi bir deneyim oldu bence." S.G.

"Alt sosyo-ekonomik düzeydeki ailelerin çocuklariyla bu projede bulunmus olmam bana ilerideki ögretmenlik hayatımda aynı şartlar altında bulunan çocuklara nasıl bir yaklaşım içerisinde bulunmam konusunda deneyim kazandırdı" H.Ç. 
Projelerin hazırlık ve uygulama sürecinde aday öğretmenler $(n=3)$ yaptıkları görüşmeler sırasında "Sivil toplum kuruluşları ve kurumlarla tanışma ve bilgi sahibi olma" kategorisine ilişkin deneyim elde ettiklerini belirtmişlerdir:

"Belirlediğimiz hedef kitle ile çalı̧san Sivil Toplum Kuruluşları'yla irtibata geçerek o kuruluşlar ve kuruluşlarda gönüllü olarak çallş̧mak için gerekli gönüllü̈lük esasları hakkında bilgi sahibi oldum" G.K.

“... bu proje sayesinde Sivil Toplum Kuruluşları, görevleri, ne tür Sivil Toplum Kuruluşları olduğu gibi pek çok konu hakkında daha detaylı bilgi sahibi olma şansina eriştim" Y.A.

\section{Projenin Topluma Kazandırdıklarına İlişkin Bulgular}

Aday öğretmenler $(\mathrm{n}=8)$, geliştirmiş oldukları projeleri çok farklı ortamlarda gerçekleştirmiş ve bunun hedef grupları için önemini "Çocuklara farklı deneyimler (materyal, etkinlik, ortam...) edinme firsatı sunma" kategorisi kapsamında açıklamışlardır:

"Topluma katkısı açısından proje değerlendirilirse çocukları farklı bir ortamda farkl deneyimlerle buluşturmamızın yararlı olduğunu düşünüyorum. Çocuklar bir üniversite ortamı görme firsatı yakaladılar ve fakültenin tüm imkânlarından (oyuncak müzesi, drama, resim, müzik derslikleri ve bahçe) faydalandılar" M.K.

"Belki de çocuklar şu ana dek elde edemedikleri firsatlart yakalamışlardır. Mesela, sinemaya daha önce hiç gitmeyenler animasyon filminin gösterilmesi ile sinema ortamın tadabilmişlerdir" S. $\ddot{U}$.

"Okulöncesi yaş grubu çocukları ilk kez suluboya, parmak boyası ile karşslaş̧tı. Bir tanesi ilk kez makas ve uhu ile karşslaş̧tı. Bunlar çocuklar için farklı birer deneyim oldu" Y.A.

"Proje amacı doğrultusunda hedef kitlenin bilgi ve farkındalık kazanması" kategorisi ise, oluşturmuş oldukları projelerin içeriği ne olursa olsun aday öğretmenlerin $(\mathrm{n}=7)$ önemsediği bir diğer durumdur. $\mathrm{Bu}$ kategoriye ilişkin verilen örneklerden bazıları yaşadıkları süreç hakkında önemli bilgiler vermektedir:

“.... Velilerden aldığım geri bildirimlere göre ailelerin beyinlerindeki klasik okulöncesi eğitim görüsü̈nün ylkıldığın görüyorum. Yani artık, okulöncesi eğitim kurumlarının sadece resim yapılan, oyun oynanan bir yer olmasinin ötesinde çocuklarının her alanda gelişimlerine destek olan bir kurum olduğu düşüncesinin aşılandığını gördüm. Bu projeden sonra velilerden bir kaçı çocuklarını okul öncesi eğitim kurumlarına gönderme kararı aldı" Y.A.

"Bu proje (Homofobi ve Transfobiye Son!) ile Eğitim Bilimleri Fakültesi'nde yani geleceğin ögrretmenlerinde bir farkindalı 
yarattı̆̆ımızı ve akıllarına onları araştırmaya itecek bir soru işareti kondurduğuтuzu düşünüyorum." G.E.

Aday öğretmenler $(\mathrm{n}=6)$ amacı ne olursa olsun planlanan etkinliklerin ilgi çekici ve etkili olması için "Proje amacı doğrultusunda hedef kitlenin eğitici ve eğlenceli bir süreç yaşaması" kategorisine önem vermiştir. $\mathrm{Bu}$ doğrultudaki görüşlerden bazıları şöyledir:

"8 haftalı süreci çocukların kısa bulmuş olmaları da ders kapsamında yürütülen eğitimin çocuklar için eğitici aynı zamanda da ĕglenceli olduğunu gösterdi.” M.K.

"Uygulama grubundaki çocukların çoğu okulöncesine gitmemişlerdi. Bilişsel, sosyal-duygusal, psikomotor, dil, özbakım becerileri yönünden zayıftılar. Uygulama yaptı̆̆ımız 8 hafta boyunca çocukların bu gelişim alanlarında desteklendiğini ve gelişim gösterdiğini gözlemledim. Ayrıca çocuklara uyguladığımı eğlenceli etkinlikler sayesinde çocukların mutluluklarını gözlemledim." S.G.

Geliştirilen projeler kapsamında önemsenen noktalardan biri de "Çocukların yaratıcılığının desteklenmesi" olarak belirtilmiştir. Aday öğretmenlerin $(\mathrm{n}=2)$ bu kategoriye ve sürece ilişkin bakış açıları aşağıdaki örneklerden anlaşılmaktadır:

"Proje süresince çocuklarla yapılan farkl etkinlikler sayesinde çocuklar hemen her etkinlikte düşünmeye yönlendirilmiş, özgürce düşünmeleri ve yapttklarl sanat etkinliklerinde özgür hareket etmeleri sağlanmıştır. Bu şekilde tamamıyla özgün ve değişik ürünler ortaya koymaları sağlanmiştır. Yapılan etkinliklerde çocukların düşüncelerine yön verilmemiş, onların düşüncelerinin yanlış ya da doğru olduğu söylenmemiş;; tam tersine istedikleri şekilde başkalarından bağımsı olarak düşünmeleri sağlanarak yaratıcllkklarının gelişmesine katkıda bulunulmuştur. "S. Ü.

"Artık materyallerle çalışmamız çocuklarda geri dönüşüm fikrini daha da gelişstirdi. Bu nesneleri işe yarar hale getirmeleri hem yaratıclıklarını geliștirdi hem de mutlu olmalarını sağladı. M.K.

\section{Projeyi Uygularken Karşılaşılan Güçlüklere İliş̧in Bulgular}

Aday öğretmenler, ders kapsamında özellikle projelerin hazırlık ve uygulama sürecinde "Sivil Toplum Kuruluşları ve Kurumlarla işbirliği yapmada güçlük" kategorisine vurgu yapmışlardır. Aşağıdaki örnekler bu süreçte yaşadıkları sorunları tüm açıklığı ile yansıtmaktadır $(n=7)$ :

\footnotetext{
"Başvurduğumuz kuruluşların çoğundan yakın bir zamana randevu alamadı̆̆ımız için veya yapacă̆ımız projeyi beğenmediklerinden ötürü projemize hemen başlayamadık. Bazı sivil toplum kuruluşları ise
} 
ancak kendi programlarının yürütülmesi şeklinde çalışllabileceğini öne sürerek projemizi uygulamamıza izin vermediler. Çalışmak istediğimiz bazı sivil toplum örgütlerinden hiçbir anlamda destek göremedik. Bazı sivil toplum örgütlerine ise onca aramamıza karşın ulașamadık."S.Ü.

"Yürüttügüumüz uygulamada en büyük güçlüğ̈̈ uygulama öncesi kurumdan onay beklerken yaşadık. Çünkü onayımız iki hafta sonra geldi. Bu iki hafta süresince kurumun onay verip vermeyeceği endişesini yaşadık.” S.G.

"Onların projelerine dâhil olmak ve bu çatı altında kendi projemizi yürütmek istiyorduk fakat dâhil olmak istediğimiz projenin durdurulduğu, diğer projenin ise maliyetinin fazla olduğu cevabını aldı. Bu proje için yüksek bir meblağı karşılayacak sponsor bulmamız önerisi verildi. Daha sonra “... Merkezi” ile görüsmeye karar verdik. Illk başta ve projemizi çok sıcak karşılamalarına rağmen, projemizi dilekçe ile sunduğumuzda bu kadar vakit ayıramayacaklarını söyleyerek reddettiler. Ardından birçok sivil toplum kuruluşuna başvurduk fakat ret cevabı aldlk." Y.A.

"Projenin hedef kitlesine (dinleyici, aile, çocuk) ulaşmada güçlük" kategorisi projelerini uygularken karşılaşmış oldukları farklı bir sorun olarak belirlenmiştir. Aday öğretmenlerin $(\mathrm{n}=5)$ bu aşamada yaşadıkları sorunlar aşağıda yer alan birkaç örnekte açıkça görülmektedir:

"Kurumlardan bağımsız olarak uyguladı̆̆ımız projede sokakta karşılaşılan bazı ailelerin bizi endişe ile karşılaması onları ikna etmemizi zorlaştırd. Bazı ailelerin ise onay verip daha sonra çocukların getirmemeleri beklediğimizden az sayıda çocukla çalışmamiza neden oldu." M.K.

"Yaşanlan diğer bir sorun ise proje konusunun (Homofobi ve Transfobiye Son!) hassas bir mevzu olmast dolaylslyla her etkinlikte katılımcı stresinin yaşanması". E.Ö.

Öğretmen adayları ders kapsamında çok farklı gruplarla çalışmayı ve özellikle bu uygulamalara en çok ihtiyacı olduklarını düşündükleri bölgeleri seçmeyi hedeflemişlerdir. $\mathrm{Bu}$ nedenle de zaman zaman "Projenin uygulandığı mekâna ulaşımda güçlük" yaşamışlardır $(\mathrm{n}=4)$ :

"Uygulamaya giderken karşılaştı̆̆ım en büyük sorun, ulaşım sorunu idi. Çünkü 10.00'da uygulama yerinde olmak için 08.00'de evden çımam gerekiyordu. 45 dakika yol uygulamadan önce bizi fazlasiyla yıpratıyordu." A.Ş.

Aday öğretmenler $(\mathrm{n}=3)$ bu proje sürecine başlamadan önce, yaşadıkları olumsuz çevre şartlarından ötürü gelişimlerinde farklılık görülen veya herhangi bir kronik rahatsızlığı olan çocuklarla uygulama yapmamış 
olduklarından güçlükler yaşadıklarını belirtmişlerdir. "Projenin hedef kitlesini oluşturan katılımcıların hastalık vb. özel durumlarına bağlı güçlükler" kategorisine ilişkin ifadeler şöyledir:

"Yaşadığımız zorluklar çocukların makineye ellerinden ya da göbeklerinden bağll olmaları nedeniyle hareketli etkinliklere yer veremememizdi." S.G.

"Çocuklar kemoterapiden sonra ağrıları olduğu için diğer çocuklarla aralarında geçen ufak bir anlaşmazlıkta ağlamaya başllyorlardl. ...etkinlik ortasinda hemşireler kan almak, tansiyon ölçmek için geldiklerinden dolayı etkinliklerin bütünlüğ̈̈ bozuluyordu. ” Z.U.

"Proje uygulayıcılarının işbirliğinde zorluk" kategorisi de karşılaşılan güçlüklerden biri olarak belirtilmiştir. Aday öğretmenler çalışmak istedikleri grup arkadaşlarını kendileri belirlemiş olmalarına rağmen, bu aday öğretmenin $(\mathrm{n}=1)$ ifadesi aslında bir öz eleştiri olarak değerlendirilebilir: “...ylllarca bireysel olarak eğitim almış bizlerin, çok yoğun grup çalışması gereken bu projede zorlanmaları doğal bir sonuçtu belki de. Bu nedenle organizasyon sorununu aşmamı çok zor oldu. Çünkü organizasyonda herkes eşit ve tamamen istekli olarak bilfiil çallş̧mallydl." E. $\ddot{O}$.

\section{Projeyi Uygularken Karşılaşılan Kolaylıklara İlişkin Bulgular}

Projenin uygulanması sürecinde en yoğun biçimde $(n=9)$ yaşanılan kolaylık olarak "Sivil Toplum Kuruluşları ve Kurumlarla işbirliği yapma (Güleryüz, olumlu iletişim, rehberlik etme vb.)" kategorisine ilişkin yanıtlar olarak belirlenmiştir:

“... derneğe girdiğimizde oradaki insanlarn olumlu tavirlart, sevecenlikleri ve güler yüzlü yaklaşmaları bizim bu projeyi sonuna kadar yürütmemize çok yardımcı oldu. Yapılan birçok etkinlikte dernekten katılımcılarımızın da olması bu işi fazlasıyla ciddiye aldıklarını ve bizim de almamızı sağladı." Z.Ö.T.

“...vakfi yetkilileri ilk görüşmemizden itibaren bize çok yardımcı oldular ve projemizi yürütme sürecinde bizi çok desteklediler. Bize her türlü imkanı sağladılar. Kendi içlerinde çok sıcak ve iyi bir iletişsimleri var. Bu iletişim bizi de olumlu yönde etkiledi. Güzel bir süreçti.” D.G.

Proje sürecinde sivil toplum kuruluşları ile çalışmayı tercih eden aday öğretmenlerden $(\mathrm{n}=4)$ "İşbirliğgi yapılan Sivil Toplum Kuruluşları ve Kurumların projenin yürütülmesi için uygun fiziksel ortamı sağlamaları" konusundaki yanıtlar karşılaşılan kolaylıklardan biri olarak belirtilmiştir:

"Projenin uygulanmasında kolaylık olarak, oyun odasının bulunması ve orada çeşitli materyallerin olması işimizi gerçek anlamda kolaylaştırdı." Z.U. 
“...yani bu ders kapsaminda bir grupta sivil toplum kuruluşlarlyla çalışmak yerine, özellikle gecekondu semtlerinden çocuklar toplayarak projelerini yürütebilirler." Y.A.

"Dönem başında sivil toplum kuruluşları ile öğrencilerden önce görüşülmesi dersi kolaylaştırıcı olabilir. Bu şekilde kontenjan dolduğu için vakıflara alınmama durumu söz konusu olmaz. Böyle bir durumda ögrenciler çok çaba harcamayacakları için dersin amacından kopulabilir. Her grup için sivil toplum kuruluşu belirlemek yerine, ögrencilerin sivil toplum kuruluşu bulamamast durumunda yönlendirilebileceği bir kurum belirlenebilir. Ama kesinlikle kurumlardan bağımsız olarak proje yürütülmesi fikri öğrencilere yine belirtilmelidir. Bu fikrin olumlu yönleri sinifa yansittlmalı ve bu şekilde gönüllü̈lüklerini sürdürmeleri sağlanmalıdır.” M.K.

"Dersin en önemli işlevinin bizlere bir proje ürettirmek olduğunu düşünüyorum. Bu nedenle çok farkl bir deneyim oldu benim için... kendi projeni yürütmek çok yararlı ve ufku geliştiren bir şey”. E.Ö.

Yukarıda görüldüğü gibi aday öğretmenlerin proje sürecinin kurgulanmasında, kurumlarla iletişim kurma ve işbirliği yapılmasında iki farklı görüşü bulunmaktadır. Ancak bu çelişkiyi en açıklayıcı biçimde ifade eden görüş aşağıdaki gibidir:
"Kafamda oluşan tek eleştiri -kurum bulmakta zorlanmamız açısından- kurumların projelere onay vermemesi dolayısıyla ögrencilerin değil, öğretim görevlilerinin konuşması șeklinde olabilir. Ama açıkçası bu konuda tam anlamıyla öyle düşünmüyorum bunların hepsinin bir süreç olduğunu ve kurum bulmada yaşanan zorlukların da aslında bu dersin bir parçası olduğunu ve gerçekten istenirse projeyi uygulayabilecek bir kurumun bulunduğunu yaşadım. Bu da dersin kazandırabileceği bir davranıştır. " C.K.

Aday öğretmenlerden biri ise edindiği deneyimleri doğrultusunda bu dersi alacak olan aday öğretmenler için "Proje sürecinde işbirliği yapılan kurumların ileriki yıllarda proje gerçekleştirecek öğrencilerle paylaşılması" düşüncesine sahiptir.

\footnotetext{
"Seneye "Topluma Hizmet Uygulamalart" dersi kapsaminda gerçekleştirilecek uygulamalar için bu seneki uygulama yerlerinin referans olarak arkadaşlara verilmesi gerektiğini düşünüyorum." H.Ç.
}

Okulöncesi öğretmen adaylarının, "Topluma Hizmet Uygulamaları" dersi kapsamında gerçekleştirdikleri uygulamalar ile bu uygulamalara ilişkin görüş ve önerilerinin belirlenmesi amacıyla gerçekleştirilen bu çalışmanın bulguları aşağıda tartışılmıştır. 


\section{TARTIŞMA}

“Topluma Hizmet Uygulamaları” dersi 2006-2007 öğretim yılında lisans programlarının yenileştirilmesi çalışmaları kapsamında eğitim fakültelerinde yer alan öğretmenlik lisans programlarına dahil edilmiş ve 2008-2009 öğretim yılından itibaren ise uygulanmaya başlanmıştır. 17.02.2011 tarihli Yükseköğretim Genel Kurul toplantıda "Öğretmen Yetiştirme Türk Milli Komitesi” tarafindan uygun görülen "Topluma Hizmet Uygulamaları" dersine ilişkin yönergenin eğitim fakültelerinde uygulanması hususu incelenmiş ve söz konusu yönergenin Eğitim Fakültelerinde uygulanmas1 uygun görülmüştür (YÖK, 2011). 2009 yılından beri yürütülmekte olan "Topluma Hizmet Uygulamaları" dersinin YÖK tarafindan 2011 yılında uygulama yönergesi yürürlüğe konuluncaya kadar fakültelerde dersin sorumlu öğretim elemanlarının kendilerinin çizdiği çerçevede gerçekleştirdikleri düşünülmektedir. $\mathrm{Bu}$ sebeple bu çalışmada öğretim elemanları tarafından dersin yürütülmesine ilişkin olarak dersin etkin öğrenicileri olan aday öğretmenlerin görüşlerini derinlemesine inceleme ihtiyacı duyulmuştur. Aday öğretmenlerin önemli bir bölümü $(\mathrm{n}=11)$, gerçekleştirmiş oldukları projelerin topluma karşı sorumluluklarının farkına varmalarını sağlamasını kendilerine yönelik bir kazanç olarak belirtmişlerdir. Benzer şekilde Bender ve Jordaan (2007) da topluma hizmet uygulamalarının en önemli kazanımlarından birinin sosyal sorumluluk bilincinin gelişimi olduğunu belirtmiştir.

Topluma hizmette temel olan ilkelerden biri olan gönüllük, aday öğretmenler $(n=8)$ tarafından önemli bir kişisel kazanç olarak belirtilmiştir. Amerika Birleşik Devletleri'nde gerçekleştirilen uygulamalarda öğrencilerin kaynak geliştirme, spor, eğitim, sağlık, sosyal ve ulaştırma alanlarında olmak üzere planlama ve/veya organizasyon işlerinde gönüllü hizmet verdikleri ve her geçen yıl bu ögrencilerin sayısında artış olduğu görülmüştür (Edwards, Mooney ve Heald, 2001). Çetin ve Sönmez (2009) tarafından sosyal bilgiler öğretmen adaylarının topluma hizmet uygulamalarını değerlendirmelerine yönelik yapılan bir çalışmada da öğrenciler topluma hizmet uygulamalarında gönüllülüğün esas olması gerektiği vurgulanmıştır.

Ülkemizde eğitim fakültelerinin her yıl artan öğrenci sayısı göz önüne alındığında, öğrencilerin gönüllü çalışmalarla "Topluma Hizmet Uygulamaları" dersi kapsamında başladıkları bu süreci, öğrenim yaşantıları tamamlandıktan sonra da devam ettirmeleri beklenmektedir. Hali hazırda var olan öğrenci potansiyelinden hem kendileri hem de bulundukları çevre için anlamlı ve işlevsel olarak yararlanılması ancak gönüllü çalışmaların desteklenmesiyle mümkün olacaktır.

Özgüven sahibi olma, organizasyon gerçekleştirebilme, ailelerle iletişim kurma ve problem çözme bir öğretmen için gerekli ve vazgeçilmez 
niteliklerdir. Katılımcı aday öğretmenlerin "Topluma Hizmet Uygulamaları" dersi kapsamında yürüttükleri projelerde edindikleri kazanımları ifade ederken bu nitelikleri ayrıntılı olarak vurguladıkları görülmektedir. $\mathrm{Bu}$ niteliklerin hizmet öncesi aday öğretmenlerde oluşmaya başlaması, mezuniyet sonrası hizmet sırasında da mesleki yaşantılarında doyum yaşamalarında etkili olabileceği düşünülmektedir. Tanrıseven ve Yelken (2011) de öğretmen adaylarının topluma hizmet dersine ilişkin kazanımlarını inceledikleri çalışmada; öğretmen adaylarının çoğunluğunun dersin toplumsal sorunlara çözüm üretme imkânı verdiğini belirtmişlerdir. Ayrıca, öğretmen adaylarının dersin topluma hizmet uygulamalarına yönelik proje geliştirme becerilerini arttırdığ 1 , projede yapılacak işleri ayrıntılı bir şekilde planlama ve proje uygulama becerilerinin geliştiği fikrine çoğunlukla katıldıkları belirlenmiştir.

Aday öğretmenlerin bir bölümü $(n=8)$, uyguladıkları projelerin, proje konusu hakkında kendilerine bilgi ve farkındalık kazandırdığını belirtmişlerdir. Aday öğretmenler proje konularını seçmede özgür olduklarından, aslında kişisel ilgi ve merakları doğrultusunda olan alanlarda projeler yürütmüşlerdir. Bu noktada bilgi edinmede artış ile farkındalık kazanma konusunda yarar sağladıkları söylenebilir.

Tüm öğretmenlik alanlarında uygulamalı çalışmalar, mesleğe hazır oluşu sağlamada temel unsurdur. Bu durum katılımcı aday öğretmenlerin lisans öğrenimlerine başlamalarından itibaren öğretim elemanları tarafından vurgulanmaktadır. Aday öğretmenler lisans öğrenimlerinin altıncı döneminde devam etmekte oldukları bu ders kapsamında toplumun farklı kesimlerinden gelen bireylerle (aile, çocuk vb.) çalışma deneyimi edindiklerini belirtmişlerdir. Elma, Kesten, Kıroğlu, Uzun, Dicle ve Palavan (2010) tarafından yürütülen çalışma sonuçları da öğretmen adaylarının "Topluma Hizmet Uygulamaları" dersinde farklı toplumsal kesimlere yönelik geliştirdikleri projeler sayesinde iletişim, dayanışma, sorumluluk duygusu ve sorunlara çözüm üretme duyarlılığı gibi konularda sosyalleşmelerine katkı sağladığını göstermiştir.

Genç yetişkin olan aday öğretmenlerin üyesi oldukları toplumun gelişimine katkı sağlamada gerek mesleki gerekse kişisel yaşantılarında işbirliği yapabilecekleri kurum ve kuruluşlarla tanışma ve kuruluşların çalışma alanları konusunda bilgi sahibi olmaları dersin bir başka kazanımı olarak yorumlanabilir. Elma ve diğ. (2010)'e göre farklı kurumları tanımak ve işleyiş̧lerini öğrenmek," Topluma Hizmet Uygulamaları" dersinin amaçlarından olan öğretmen adayının gerçek yaşam ile okul arasındaki ilişkiyi kurmasına yardımcı olacaktır.

Aday öğretmenler projelerde hizmet götürdükleri grupların özellikleri ve ihtiyaçlarını belirleyerek planlama yapmışlardır. $\mathrm{Bu}$ planlamalar 
uygulamaya dönüştüğünde ise hedef kitlenin ihtiyaçlarının imkânlar doğrultusunda mümkün olduğunca farklı materyal, etkinlik ve ortam sağlayarak karşılanması gerçekleştirilmiştir.

Aday öğretmenlerin yürüttükleri altı projeden beşi farklı özellikte ve düzeyde çocuklara eğitim hizmeti sunmayı amaçlamıştır. Projelerin topluma kazandırdıklarına ilişkin aday öğretmen görüşleri eğitim hizmetinin eğlendirici, öğretici ve çocukların yaratıcılıklarını destekleyici olduğu yönündedir.

Uygulanan projeler sonucunda çalışlan alanlarda bilgi ve farkındalık elde eden aday öğretmenler, hedef kitlelerinin de, götürdükleri hizmet konusunda (farklı düzeylerde eğitim, homofobi ve transfobi) derinlemesine bilgi kazandıklarını düşünmektedirler.

Aday öğretmenler projelerinde ihtiyacın diğer bölgelere oranla daha fazla olduğunu düşündükleri bölgeleri seçmeyi ve farklı gruplarla çalışmayı amaçlamışlardır. Belirlenen bu bölgelerin bazen mekâna ulaşım açısından sorun yaşanmasına neden olduğu belirtilmiştir $(n=4)$. Yaşanan bu sorunun uygulamaların niteliğini etkilememesi için büyük çaba sarf ettiklerini de eklemişlerdir. $\mathrm{Bu}$ açıdan bakıldığında, topluma hizmet uygulamalarının; hizmet verilecek kitlenin niteliğinin yanı sıra, uygulamayı gerçekleştirecek öğrencilerin mekâna ulaşım vb konularında da onların beklentilerini karşılar nitelikte olmasına özen gösterilmelidir (Fritz, 2002).

Aday öğretmenlerin bir bölümü $(n=9)$ dersin yürütülmesi konusunda "Sivil Toplum Kuruluşları ve kurumlarla öğretim elemanlarının önceden görüşmesi" gerektiği konusunda öneride bulunurken, bir diğer bölümü $(n=9)$ ise "Proje sürecinin öğrencilerin kişisel çabalarıyla (Sivil Toplum Kuruluşları ve kurumlardan bağımsız) yürütülmesi" kategorisine ilişkin görüş bildirmiştir. Dersin yürütülmesi sırasında aday öğretmenler geliştirecekleri projelerde Sivil Toplum Kuruluşları ve kurumlarla çalışıp çalışmamak konusunda öğretim elemanları tarafından kişisel kararlarının almak konusunda sınırlandırılmamışlardır. Bu bulgu, aday öğretmenlerin projelerin planlanması ve yürütülmesi sırasında Sivil Toplum Kuruluşları ve kurumlarla yaşadıkları olumlu ve olumsuz deneyimlerle açılanabilir. Toplum liderliği olarak görülen "öğretmenlik mesleği”ni gerçekleştirmek konusunda ilerleyen aday öğretmenlerin karar verme becerilerini geliştirmek önemli bir adımdır. Bu nedenle ders kapsamında geliştirilecek projelerin planlama, uygulama ve değerlendirme süreçlerinde karar vermelerine ve inisiyatif kullanmalarına firsat tanımak amacıyla öğretim elemanlarının etkinlik düzeylerini azaltarak, rehberlik etmeleri gerekmektedir. Elma ve diğg. (2010)'nin yaptıkları çalışmada aday öğretmenler uygulama yapılacak kurumların belirlenmesinde öğretim elemanlarının daha az etkin olmasını düşündüklerini belirtmişlerdir. 


\section{SONUÇ VE ÖNERILER}

Okulöncesi öğretmen adaylarının, "Topluma Hizmet Uygulamaları" dersi kapsamında gerçekleştirdikleri uygulamalar ile bu uygulamalara ilişkin görüş ve önerilerinin belirlenmesi amaci ile gerçekleştirilen bu çalışmada elde edilen sonuçlar aşağıda görülmektedir:

Aday öğretmenler yürüttükleri projeler kapsamında; toplumsal duyarlılıklarının arttığı ve sorunları çözmede sorumluluk aldıkları, toplumun farklı kesimlerindeki bireylerle iletişim kurma deneyimleri edindiklerini belirtmişlerdir. Aday öğretmenler proje planlama ve uygulama boyutlarında organizasyon becerilerinin geliştiğini, topluma hizmet sunmada gönüllülüğün esas oluşunu kavradıklarını, kişisel doyum ve özgüven duygusu yaşadıklarını vurgulamışlardır. Ayrıca aday öğretmenler, çalıştıkları proje konusu hakkında bilgi ve farkındalık kazandıklarını, kısa süreli de olsa öğretmenlik deneyimi edindiklerini, sivil toplum kuruluşları ve kurumlar hakkında bilgi sahibi olduklarını ifade etmişlerdir.

Aday öğretmenler projeler kapsamında toplumun kazanımları olarak; hedef kitlesi çocuklardan oluşan projelerin, gruba farklı deneyimler (materyal, etkinlik, ortam gibi) edinme firsatı sunduğu, amaçlar doğrultusunda hedef kitlelerin bilgi ve farkındalık kazandığı ayrıca hedef kitlelerdeki çocukların eğitici ve eğlenceli bir süreç yaşayarak yaratıc1lıklarının desteklendiği görüşlerini belirtmişlerdir.

Aday öğretmenlerin süreçte yaşadıkları güçlüklerin sivil toplum kuruluşları ve kurumlarla işbirliği kurmada, hedef kitleye (dinleyici, aile, çocuk) ulaşmada, uygulama yapılan mekâna ulaşımda, hedef kitlenin bireysel özellikleri (kronik hastalıklar ve tedavi koşulları) konularında yaşandığı belirlenmiştir.

Aday öğretmenlerin proje sürecini kolaylaştıran unsurlar ise; sivil toplum kuruluşları ve kurumlarla işbirliği kurduktan sonra gerekli destek ve rehberlikten yararlanma ve bu kurumların projenin yürütülmesi için uygun fiziksel ortamı sağlamaları olarak belirlenmiştir. Ayrıca hedef kitlesi okul öncesi dönem çocuğu olan proje grupları eğitimini aldıkları alanda çalışma imkânını kolaylık olarak görmektedirler.

Derse ilişkin önerilerde ise proje sürecinin aday öğretmenler ya da dersin öğretim elemanları tarafından kurgulanması konusunda iki farklı görüş vardır. Ayrıca proje sürecinde işbirliği yapılan kurumların ileriki yıllarda proje gerçekleştirecek öğrencilerle paylaşılması önerisi getirilmiştir. $\mathrm{Bu}$ sonuçlar doğrultusunda, aday öğretmenlerin süreçten edindikleri toplumsal duyarlılık edinme ve sorumluluk alma gibi kazanımların aslında katılımcı vatandaş olma konusunda bir başlangıç niteliği taşıdığ 1 düşünülmektedir. $\mathrm{Bu}$ noktada ülkemizdeki eğitim fakültelerinin öğrenci potansiyeli dikkate alındığında "Toplum Hizmet Uygulamaları" dersinin 
sadece mesleki gelişime katkı sağlamakla kalmadığı aynı zamanda birey olarak kişisel gelişime de katkı getirdiği belirlenmiştir.

Ayrıca yüksek öğrenim düzeyine gelen aday öğretmenlerin lisans programının altıncı döneminde yürütecekleri projenin kurgulanmasında ilk elden girişim ve sorumluluğu almada sorun yaşadıkları görülmüştür. Bunun olası nedeni olarak görülebilecek ezberci ve hazırcı eğitim anlayışının değişimi için, lisans öğreniminin ilk dönemlerinden başlayarak öğretim elemanları ile öğrenciler arasında öğrenmenin sorumluluğunun paylaşılmasına imkân veren ders içeriklerinin düzenlenmesi önerilmektedir. Yürütülen projelerin büyük bölümünün hedef kitlesinin aday öğretmenlerin öğrenimlerini tamamladıktan sonra çalışacakları okulöncesi çocuklardan oluşması etkinliklerin planlanması, uygulanması ve değerlendirilmesinde bir avantaja dönüşmüştür. $\mathrm{Bu}$ konuda belirtilen görüşlerde lisans derslerinde edinilen kuramsal bilgilerin uygulamaya aktarılmasında başarı sağlandığ belirtilmektedir. Dolayısıyla topluma hizmet uygulamalarında; hizmete gereksinim duyabilecek toplumun her kesiminden insanların yanı sıra, aday öğretmenlerin eğitimini aldıkları yaş grubuna yönelik de projeler oluşturmaları önerilebilir. Bunlara ek olarak; Topluma Hizmet Uygulamaları dersinde uygulanan projelerin ve yaşanan deneyimlerin gelecek yillarda bu dersi alacak olan öğrencilerle paylaşılması, sivil toplum kuruluşları ile gerekli bağlantıların önceden yapılarak daha sıkı bir işbirliği içinde projelerin yürütülmesi, öğrencilerin ulaşımda zorlanmayacakları kurumlarda projelerini gerçekleştirmeleri önerilebilir.

\section{KAYNAKLAR}

Anonim (2009). Ankara Üniversitesi Eğitim Bilimleri Fakültesi Topluma Hizmet Uygulamaları Komisyonu Yayımlanmamış Öğrenci Ders Tanıtım Broşürü, Ankara.

Astin, A.W. \& Sax, L. J. (1998). How undergraduates are affected by service Participation. Journal of College Student Development,39(3), 251-263.

Aytekin, N.T. (2002). Topluma yönelik - topluma dayalı tıp eğitimi. Uludă̆ Üniversitesi Tip Fakültesi Dergisi, 28(2), 53-56.

Bender, G. \& Jordaan, R. (2007). Student perceptions and attitudes about community service-learning in the teacher training curriculum. South African Journal of Education, 27, 651-634.

Bilgin, N. (2006). Sosyal Bilimlerde İçerik Analizi. Ankara: Siyasal Kitabevi.

Büyüköztürk, Ş., Kılıç Çakmak, E., Akgün, Ö.E., Karadeniz, Ş. ve Demirel, F. (2010). Bilimsel Araştırma Yöntemleri (5.Baskı). Ankara: Pegem Akademi Yayınc1lik.

Coşkun, H. (2009). Topluma Hizmet Uygulamaları. Ankara: Anı Yayıncılık.

Çetin, T. ve Sönmez, Ö.F. (2009). Sosyal bilgiler öğretmen adaylarının topluma hizmet uygulamaları dersinin amaç ve içeriğine yönelik görüşlerinin değerlendirilmesi. Gazi Eğitim Fakültesi Dergisi, 29(3), 851-875. 
Dinçer, Ç. , Ergül, A. , Şen, M. ve Çabuk, B. (2011). Bir topluma hizmet uygulaması örneği: "Haydi kavram oyuncaklarıyla oynayalım" Kastamonu Üniversitesi Eğitim Fakültesi Dergisi, 19 (1), 19-38.

Edwards, B., Mooney, L. and Heald, C. (2001). Who is being served? The impact of student voluntering on local community services. Nonprofit and Voluntary Sector Quarterly. 30 (3), 444-461.

Elma, C., Kesten, A., Kıroğlu, K., Uzun, E. M., Dicle, A. N. ve Palavan, Ö.(2010). Öğretmen adaylarının topluma hizmet uygulamaları dersine ilişkin algıları. Kuram ve Uygulamada Ë̆itim Yönetimi, 16 (2), 231-252.

Fritz, J.M. (2002). A little bit of sugar: integrated service-learning courses. Sociological Practice: A Journal of Clinical and Applied Sociology, 4(1), 6777.

Haktanır, G., Akgün, E., Duman, G. ve Karaman, G. (2010). “Topluma hizmet uygulamaları dersi ile ilgili örnek bir uygulama." (Basılmamış Kongre Bildirisi). 7. Eğitimde İyi Örnekler Konferansı, İstanbul.

Herzberg, B. (1994). Community Service and Critical Teaching. College Composition and Communication, 45(3), 307-319.

McLellan, J.A. \& Youniss, J. (2003). Two Systems of Youth Service: Determinants of Voluntary and Required Youth Community Service. Journal of Youth and Adolescence, 32(1), 47-58.

Niemi, R.G., Hepburn, M.A. \& Chapman, C. (2000). Community service by high school students: a cure for civic ills? Political Behavior, 22(1), 45-69.

Parker, E.A., Myers, N., Higgins, H.C., Oddsson, T., Price, M. \& Gould, T. (2009). More than experiential learning or volunteering: a case study of community service learning within the Australian context. Higher Education Research \& Development, 28(6), 585-596.

Rashotte, L.S. (2002). Service learning in a small groups course. Sociological Practice: A Journal of Clinical and Applied Sociology, 4(1),79-87.

Schmidt, H., Magzoub, M., Feletti, G., Nooman, Z. \& Vluggen, P. (2000). Handbook of Community - Based Education: Theory and Practices. Maastricht: Network Publications.

Şeker, A. (2009). Topluma Hizmet Uygulamaları (1.Basım). Ankara: Nobel Yayın Dağıtım.

Tanriseven, I. ve Yelken, T. (2011). Topluma hizmet uygulamaları dersinin öğretmen adaylarının görüşlerine göre değerlendirilmesi. e-Journal of New World Sciences Academy Education Sciences, 6(1), 415-428 Article Number: $1 \mathrm{C} 0303$.

Yıldırım, A. ve Şimsek, H. (2006). Sosyal Bilimlerde Nitel Araştırma Yöntemleri (Altıncı Baskı).Ankara: Seçkin Yayıncılık.

YÖK (2011).Topluma Hizmet Uygulamaları Dersi Yönergesi.(Öğretmen Yetiştirme Türk Milli Komitesi ile 17.02.2011 tarihli Yükseköğretim Genel Kurul toplantısında eğitim fakültelerinde uygulanması karara bağlanan ve Eğitim Fakülteleri Dekanlıklarına gönderilen yönerge). 
